\title{
KebANGKITAN KeMbali RUH PROFETISME MUHAMMADIYAH: TINJAUAN TRANSFORMASI SOSIAL
}

\section{- Hasnan Bachtiar}

Universitas Muhammadiyah Malang, Indonesia

Email: bachtiar@umm.ac.id

\begin{abstract}
Abstrak
Paper ini menjelaskan bagaimana profetisme sebagai sebuah spirit menginspirasi gerakan sosial Muhammadiyah hingga mencapai posisi yang kokoh, kendati menghadapi pelbagai tantangan gelombang besar globalisasi. Penggunaan pendekatan transformasi sosial untuk membaca situasi kekinian, menemukan bahwa Muhammadiyah cukup tergoncang menghadapi kekuatan kapitalisme baru yang bekerja melalui arus sistem-sistem pasar yang menjangkau seluruh dimensi kehidupan. Pada akhirnya, bagian utama pada paper ini memberikan sejumlah saran untuk revitalisasi dan transformasi profetisme di dalam konteks kontemporer sebagai solusi untuk mengendalikan globalisasi.
\end{abstract}

Kata Kunci: Profetisme, Muhammadiyah, Globalisasi 


\section{Pendahuluan}

Paper ini akan menjelaskan bagaimana profetisme sebagai spirit, menginspirasi gerakan sosial Muhammadiyah untuk terus bertahan tatkala menghadapi gelombang besar globalisasi. Sebagai karya akademik, tulisan ini terbagi dalam beberapa bagian. Pertama, dalam pengantar, menjelaskan konsep riset menyangkut profetisme Muhammadiyah. Kedua, penjelasan tentang Muhammadiyah dalam perspektif sosial kemanusiaan. Ketiga, tentang gerakan Muhammadiyah sebagai gerakan sosial profetik. Keempat, tentang profetisme, Muhammadiyah dan gelombang besar globalisasi. Kelima, sebagai penutup sekaligus rekomendasi teoritis tentang membangkitkan kembali ruh profetisme Muhammadiyah.

\section{Konsep}

Dalam tulisan ini, profetisme adalah nilai, dan Muhammadiyah merupakan agen yang mentransformasikan nilai-nilai tersebut, sedangkan globalisasi adalah konteks di mana proses transformasi terjadi.

Perlu kiranya memberikan sejumlah batasan tertentu menyangkut teori profetisme dalam makalah ini untuk kepentingan akademis. Profetisme yang dimaksud dalam tulisan ini, secara literal berasal dari bahasa Inggris, yaitu prophet atau prophetic, yang bermakna nabi atau kenabian. Heddy Sri-Ahimsa Putra dalam kertas kerjanya yang berjudul "Paradigma Profetik: Mungkinkah? Perlukah?" memberikan makna bahwa, "...profetik adalah mempunyai sifat atau ciri seperti nabi, atau bersifat prediktif, prakiraan." ${ }^{1}$ Seperti nabi, profetisme berarti mengemban misi ilahiah yang termanifetasikan dalam seluruh aktivitas kemanusiaan yang luhur.

Secara teoritik, profetisme yang dimaksud merujuk pada teorisasi yang dilakukan oleh Kuntowijoyo, ${ }^{2}$ karena itu lazim disebut sebagai Ilmu Sosial Profetik (ISP). ${ }^{3}$ ISP tidak terlalu berbeda dengan ilmu sosial transformatif, yang mengelaborasi ajaran-ajaran agama ke dalam bentuk teori sosial. Tujuannya

$1 \quad$ Heddy Sri-Ahimsa Putra, Paradigma Profetik: Mungkinkah? Perlukah? (Makalah Sarasehan Profetik 2011, Sekolah Pascasarjana UGM, di Yogyakarta, 10 Februari 2011), h. 6.

2 Prof. Dr. Kuntowijoyo (1943 - 2005) adalah seorang budayawan, sastrawan, dan sejarawan dari Indonesia. Gelar kesarjanaannya diperoleh dalam bidang sejarah dari Universitas Gadjah Mada pada 1969. Gelar M.A. diperoleh dari Universitas Connecticut, Amerika Serikat pada 1974, dan meraih Ph.D. dari Universitas Columbia pada 1980. Ia mengajar di Fakultas Sastra Universitas Gadjah Mada dan terakhir menjadi Guru Besar Fakultas Ilmu Budaya, dan menjadi peneliti senior di Pusat Studi dan Penelitian Kependudukan Universitas Gadjah Mada, Yogyakarta.

3 Dalam konteks akademis, Kuntowijoyo adalah peletak dasar teori sosial profetik ini. Hal ini ditopang oleh alasan yang kuat bahwa, sepanjang penerbitan pelbagai literatur dalam bidang ilmu-ilmu sosial 
adalah rekayasa untuk perubahan sosial. Karena itu, ruang lingkupnya bukan pada aspek-aspek normatif seperti teologi, tetapi pada aspek-aspek yang bersifat empiris, historis, dan temporal. ${ }^{4}$

ISP menghendaki transformasi sosial yang berdasarkan pada cita-cita humanisasi, liberasi dan transendensi yang diderivasi dari misi historis Kitab Suci. Dalam hal ini, Kuntowijoyo merujuk pada al-Quran, surat Ali Imran ayat 110, yang artinya, "Engkau adalah umat terbaik, yang diturunkan di tengah umat manusia untuk menegakkan kebaikan, mencegah kemungkaran (kejahatan) dan beriman kepada Allah."

Menurut Kuntowijoyo, ada empat hal yang tersirat dalam ayat tersebut, yaitu tentang konsep umat terbaik, aktivisme sejarah, pentingnya kesadaran dan etika profetik. ${ }^{5}$ Pertama, umat manusia akan menjadi umat terbaik, tatkala mampu melaksanakan "pengabdian kemanusiaan" bagi umat manusia (civil society); Kedua, mengemban misi kemanusiaan, berarti berbuat untuk manusia dalam bentuk aktivisme sosial dan membentuk sejarah; Ketiga, kesadaran dimaksud adalah kesadaran ilahiah. ${ }^{6}$ Dengan kata lain, suatu bentuk "keterpanggilan etis" untuk kemanusiaan yang dilandasi oleh spirit teologis; Keempat, etika profetik ini berlaku umum, yaitu menyeru kebaikan, mencegah kemungkaran dan beriman kepada Allah (transendensi). ${ }^{?}$

dan humaniora hingga tahun 2012, sejauh penelitian penulis, belum ada yang membahas tentang ilmu sosial profetik ini, kecuali menyandarkan diri pada nama Kuntowijoyo. Memang ada satu literatur, datang dari Roger Garaudy, dalam bab khusus yang berjudul "Filsafat Kenabian", namun tidak membicarakan ilmu sosial profetik. Tulisan tersebut adalah uraian-uraian dalam bidang filsafat spekulatif. Lihat Roger Garaudy, "Filsafat Kenabian," Janji-Janji Islam (Jakarta: Bulan Bintang, 1985), h. 135-167. Gagasan epistemologis menyangkut ISP, bisa merujuk pada Kuntowijoyo, Islam sebagai Ilmu: Epistemologi, Metodologi dan Etika (Yogyakarta: Tiara Wacana, 2006). Lihat Kuntowjoyo, "Ilmu Sosial Profetik: Etika Pengembangan Ilmu-Ilmu Sosial,” Muslim Tanpa Masjid (Bandung: Mizan, 2001), h. 357-376. Lihat pula penjelasan dan kritik menyangkut teori ini dalam Heddy Sri-Ahimsa Putra, Paradigma Profetik: Mungkinkah? Perlukah? (Makalah Sarasehan Profetik 2011, Sekolah Pascasarjana UGM, di Yogyakarta, 10 Februari 2011).

4 Kuntowijoyo, "Etika Paradigma Islam," Islam sebagai Ilmu: Epistemologi, Metodologi dan Etika (Yogyakarta: Tiara Wacana, 2006), h. 85.

5 Kuntowjoyo, "Ilmu Sosial Profetik: Etika Pengembangan Ilmu-Ilmu Sosial," Muslim Tanpa Masjid (Bandung: Mizan, 2001), h. 357.

6 Secara konsepsional, "kesadaran ilahiah" yang dimaksud serupa dengan "kesadaran kritis" menurut terminologi Paulo Freire. Lihat Paulo Freire, Pedagogy of the Oppressed (New York: the Continuum International Publishing Group Inc., 2000), h. 87-124. Paulo Freire, Education for Critical Consciousness (New York: the Continuum International Publishing Group Inc., 2007), h. 37-52. Paulo Freire, Pedagogy of Hope: Reliving Pedagogy of The Oppressed (New York: the Continuum International Publishing Group Inc., 2006).

7 Kuntowijoyo, Ibid., h. 357-358. 
Khusus menyangkut penjelasan yang terakhir disebutkan, etika profetik memiliki tiga prinsip utama, yaitu humanisasi, liberasi dan transendensi. Pertama, humanisasi bermakna memanusiakan manusia. ${ }^{8}$ Di hadapan situasi kontemporer, di mana kehidupan masyarakat tradisional berubah menjadi situasi industrial, dengan demikian merubah pula pola-pola kebudayaan yang ada. Kemanusiaan, kadangkala tergantikan atau bahkan tidak lebih penting dari kepentingan industrialisme. Orientasi profit yang dijalankan melalui cara produksi membentuk pola pikir manusia yang konsumtif.. Dengan demikian, barang, mesin, uang dan kepentingan pasar merupakan prioritas dari pada kemanusiaan, yang hanya melayani dan dapat dirasakan manfaatnya oleh sebagian orang saja, khususnya pemilik kapital. Berseberangan dengan hal ini, maka mereka yang jauh dari kepemilikan modal, menjadi miskin, termarginalkan dan tersisih dari komunitas industrial (teralienasi). Humanisasi, seperti yang dimaksud dalam ISP, merupakan paradigma, di mana kesadaran kemanusiaan untuk memanusiakan manusia yang diupayakan untuk menjawab pelbagai problem masyarakat industrial tersebut.

Kedua, liberasi adalah upaya untuk menetralisir segala bentuk tindak laku yang dehumanistik atau anti-kemanusiaan. ${ }^{9}$ Upaya ini menjadi sangat penting, karena dalam setiap struktur sosial, khususnya dalam konteks masyarakat industrial-kapitalistik, tidak hanya ada para pemilik modal dan pekerja, namun juga berlangsung sistem dominatif, hegemonik dan eksploitatif. Dengan kata lain, ada kelas yang menindas, ada pula yang tertindas. Liberasi sebagai prinsip etika profetik, berguna untuk membuat netral kondisi "penjajahan" tersebut. Liberasi, bermakna pembebasan atau pemerdekaan bagi kemanusiaan di hadapan sistem sosial yang tiranik.

Ketiga, transendensi adalah mengembalikan segala urusan kehidupan kepada Tuhan. ${ }^{10}$ Prinsip ini sebenarnya merupakan upaya untuk mengoptimalkan

8 Kuntowijoyo, Ibid., h. 366-369. Gagasan ini pernah dipopulerkan oleh Paulo Freire, Pedagogy of the Oppressed (New York: the Continuum International Publishing Group Inc., 2000); Erich Fromm, The Fear of Freedom (London: Routledge Classics, 2001); dan Frantz Fanon, The Wretched of the Earth (New York: Grove Press, 2004).

9 Kuntowijoyo, Ibid., h. 369-372. Lihat juga Gustavo Gutierrez, A Theology of Liberation: History, Politics, and Salvation (New York: Orbis Books, 1988) dan Asghar Ali Engineer, Islam and Liberation Theology: Essays on Liberation Elements in Islam (New Delhi: Sterling Publishers, 1990).

10 Kuntowijoyo, Ibid. 372-375. Gagasan ini cukup sulit dipahami. Namun untuk mendapatkan konseptual seperti apa yang dimaksud Kuntowijoyo, bisa ditelusuri dalam buku Kuntowijoyo, Maklumat Sastra Profetik (Yogyakarta: Grafindo Litera Media, 2006). Membaca urian transendensi dalam bentuk karya sastra, akan lebih mudah untuk memahaminya. 
spiritualitas manusia, sebagai hamba. Terlebih, bahwa transendensi diharapkan menjadi nilai kesadaran umat, yang bersifat komunal atau memasyarakat. Humanisasi dan liberasi, keduanya semata-mata diupayakan karena prinsip yang transenden ini. Tuhan merupakan sumber kekuatan, keabadian dan Dzat yang Maha Obyektif. Segala upaya humanisasi dan liberasi bukanlah pemikiran dan sikap manusia yang reaktif. Upaya pembelaan terhadap kemanusiaan, misalnya dihadapan dehumanisasi yang menindas, bukan bahwa kelas penindas digantikan posisinya oleh kelas tertindas sebagai penindas baru, namun lebih kepada upaya menetralisir dan menuju pada kondisi yang obyektif.

Dari uraian singkat teori profetisme tersebut, paling tidak ada empat nilai dan tiga prinsip yang secara paradigmatik digunakan sebagai framework pada paper kali ini. Keempat nilai tersebut adalah: (1) civil society, (2) aktivisme sejarah, (3) pentingnya kesadaran, (4) etika profetik. Sedangkan prinsip-prinsip yang menopang ISP adalah humanisasi, liberasi dan transendensi. Perangkat teoritik inilah yang digunakan untuk membaca Muhammadiyah sebagai obyek penelitian.

\section{Profetisme Muhammadiyah}

Titik temu antara teoritik ini dengan Muhammadiyah, adalah dengan mencari koherensinya dengan fenomena gerakan Muhammadiyah. Gerakan Muhammadiyah yang mengamalkan profetisme akan dirumuskan dalam artikulasi teoritik.

Upaya akademik ini, dapat dimulai dari statemen penting bahwa Muhammadiyah lahir dari inspirasi, prinsip dan spirit profetisme. Gerak profetisme Muhammadiyah, memicu terjadinya perubahan sosial yang begitu besar. Kebesaran organisasi keagamaan ini, tentu saja bukan karena suatu ideologi agama yang konservatif, namun profetisme itulah yang membentuk jati dirinya.

Thesis statement profetisme Muhammadiyah, dapat diidentifikasi dan dibuktikan dari pola gerakan sosial keagamaan yang diterapkan Muhammadiyah. Ciri profetisme adalah, adanya kesinambungan antara ortodoksi dengan ortopraksi oleh Muhammadiyah. ${ }^{11}$ Dengan profetisme, persyarikatan Muhammadiyah tidak

Dalam pengertian yang sederhana, ortopraksi bermakna "amaliah". Lihat Djohan Effendi, Pembaruan

Tanpa Membongkar Tradisi. Wacana Keagamaan di Kalangan Generasi Muda NU, Masa Kepemimpinan Gus

Dur (Jakarta: Kompas, 2010), h. 68. Barangkali, makna yang lebih lugas, disampaikan oleh Abdul Munir Mulkhan. Lihat Abdul Munir Mulkhan, "Al-Quran dan Pragmatisasi Amal Saleh," Manusia alQuran: Jalan Ketiga Religiositas di Indonesia (Yogyakarta: Kanisius, 2007), h. 77-84. Lihat juga Moeslim Abdurrhaman, Islam Sebagai Kritik Sosial (Jakarta: Erlangga, 2003), h. 123. 
bermaksud mengukuhkan diri menjadi mazhab yang tekstualis, atau sematamata ortodoks terhadap teks keagamaan. Justru pilihan untuk menjadi kelompok yang sarat dengan teks Kitab Suci, merupakan hasil penghayatan yang sungguh terhadap konteks sosial yang ada. Kredo ruju' ila al-Qur'an wa al-Sunnah, bermakna pembebasan (ortopraksi).

Hal ini tentu saja, berbeda dengan stigma bahwa "kembali ke al-Qur'an dan Sunnah" dimaksudkan untuk membatasi ruang gerak kehendak bebas manusia (free will). Dengan demikian, pandangan ini menepis pendapat yang menetapkan Muhammadiyah sebagai golongan "Islam murni". ${ }^{12}$

Profetisme Muhammadiyah yang membebaskan ini, benar-benar memberikan nilai tambah, sekaligus membedakannya dengan organisasi keagamaan lain. Misalnya saja Sarekat Islam (SI/ 1912), sebagai manifestasi gerakan kaum beragama, SI telah tumbang tergilas zaman dengan pelbagai sebab. ${ }^{13}$ Nasib ini tidak berlaku pada Muhammadiyah. Justru hingga satu abad lebih, Muhammadiyah masih menunjukkan eksistensinya sebagai organisasi keagamaan yang telah mapan. Inilah bukti yang sulit dibantah dari thesis statement profetisme Muhammadiyah. Daripada memperjuangkan Islam melalui jalur politik seperti SI, Muhammadiyah lebih menaruh perhatian pada strategi kebudayaan dan pendidikan. Namun, situasi sejarah jelas selalu berubah. Yang menjadi pertanyaan fundamental adalah, dalam konteks kekinian, apakah Muhammadiyah masih mampu mempertahankan eksistensinya? Di titik inilah riset ini menjadi sangat menarik, sekaligus menjadi tantangan tersendiri, bagi studi sosial dan humaniora.

Paper ini, akan menjelaskan bagaimana Muhammadiyah sebagai lembaga sosio-religious mampu bertahan lama, hingga satu abad lebih. Secara lebih spesifik, Muhammadiyah sebagai lembaga pendidikan yang memperjuangkan Islam dan kemanusiaan, termasuk kiprahnya dewasa ini, di tengah amuk gelombang besar globalisasi yang dalam kurun waktu kontemporer, tengah menggoncang kondisi sosial kemanusiaan.

12 Kuntowijoyo, "Jalan Baru Muhammadiyah," dalam Abdul Munir Mulkhan, Islam Murni dalam Masyarakat Petani (Yogyakarta: Yayasan Bentang Budaya, 2000), h. xvii. Contoh pendapat mengkategorikan Muhammadiyah sebagai bagian dari Islam murni, dapat ditemui dalam tulisan Herman L. Beck, "The Borderline between Moslem Fundamentalism and Moslem Modernism: An Indonesian Example," dalam Jan Willen Van Henten dan Anton Houtepen (eds.), Religious Identity and the Invention of Tradition (The Nethelands: Koninklijke Van Gorcum, 2001), h. 279-291.

13 Untuk mengamati uraian sejarah SI, silahkan merujuk pada Takashi Shiraishi, An Age in Motion. Popular Radicalism in Java, 1912-1926 (Ithaca: Cornel University Press, 1990). Lihat Budy Styarso (eds.), Tjokroaminoto. Guru para Pendiri Bangsa (Jakarta: Kepustakaan Popular Gramedia, 2011). 
Sebagai suatu studi, hal ini tentu saja dibaca melalui perspektif yang berbeda dengan kebanyakan kacamata ilmu sosial positivistik. ${ }^{14}$ Fenomena Muhammadiyah, akan dibaca melalui sudut pandang transformasi sosial. ${ }^{15}$ Ilmu sosial yang memiliki cita-cita normatif, yang secara terus-menerus dimotivasi oleh kesadaran subyektif keagamaan untuk membela dan memperjuangkan keadilan sosial ekonomi, baik menyangkut analisis formasi sosial, maupun struktur kelas. ${ }^{16}$ Studi ini lebih diutamakan, bagi para peneliti insider yang ingin memberikan sumbangsih kritik ke dalam (auto-kritik), demi kemajuan komunitasnya sendiri. Dawam Rahardjo menandaskan bahwa, studi yang demikian, merupakan implementasi dari upaya pribumisasi ilmu-ilmu sosial (indigenization of social sciences). ${ }^{17}$ Dengan metode grounded research, studi ini berusaha untuk sejauh mungkin menangkap realitas dari sudut penglihatan masyarakat sendiri. Muhammadiyah dibaca, dimengerti, dianalisis, dipahami dan dikritik, - kurang lebih - menurut sudut pandang "orang" Muhammadiyah sendiri.

14 Untuk mendalami masalah kontemporer, pendekatan positivistik dirasa tidak mencukupi untuk menguraikan pelbagai akar masalah secara tepat. Karena itu, perlu eksplorasi pelbagai rumpun pengetahuan, termasuk seni, ilmu sosial dan humaniora, ketiganya sekaligus, agar pemahaman terhadap fenomena menjadi lebih koprehensif. Lihat Ishomuddin, "Interdisiplin Menuju Pemahaman Menyeluruh; Kegelisahan Seorang Sosiolog Wallerstein," Tarjih dalam Pendekatan Ilmu-Ilmu Sosial: Mengupayakan Praktek Interdisipliner dalam Bertarjih (Makalah Workshop Metodologi Tarjih Pusat Studi Islam dan Filsafat UMM, 5 Mei 2012), h. 2-8.

15 Pradana Boy ZTF., "Prophetic Social Sciences: Toward an Islamic-Based Transformative Social Sciences," IJIMS: Indonesian Journal of Islam and Muslim Societies, Vol. 1, No. 1, (Juni 2011), h. 95-121. Lihat pula narasi pidato pengukuhan guru besar Purwo Santoso, Ilmu Sosial Transformatif (Makalah Pidato Pengukuhan Guru Besar, Universitas Gadjah Mada, 19 April 2011). Dalam naskah ini, secara retoris, Santoso mengemukakan bahwa, "...saya hanya perlu mengingatkan bahwa ilmu sosial di negeri ini adalah ilmu tentang kita. Teori-teori yang dibangun orang asing tentang kebersamaan kita, merupakan ketidaksadaran kita akan arti penting masa depan kita. Pengetahuan orang asing tentang kita, pada dasamya adalah kesempatan lebih pada mereka untuk menguasai kita. Penguasaan akan ketidaksadaran kita, adalah pintu penjajahan ataupun dominasi. Apa yang terjadi kalau kendali pengembangan ilmu tidak ada pada diri kita? Ketidaksadaran tentang keseharian kita yang secara diam-diam telah mereka teorisasikan, memungkinkan mereka mengendalikan diri kita melalui ilmu pengetahuan." Sebagai peletak dasar teori ini di Indonesia, dapat merujuk pada dua nama utama, yaitu Moeslim Abdurrahman dan Kuntowijoyo. Lihat Kuntowijoyo, "Etika Paradigma Islam," Islam sebagai Ilmu: Epistemologi, Metodologi dan Etika (Yogyakarta: Tiara Wacana, 2006), h. 85-89.

16 A.E. Priyono, "Periferalisasi, Oposisi dan Integrasi Islam di Indonesia. Menyimak Pemikiran Dr. Kuntowijoyo," Kuntowijoyo, Paradigma Islam: Interpretasi untuk Aksi (Bandung: Mizan, 1991), h. 41.

17 Pribumisasi yang dimaksud adalah melepaskan tendensi peradaban tertentu sebagai fondasi etis setiap ilmu sosial, khususnya ilmu sosial Barat. Dengan demikian, ilmu sosial pribumi adalah hasil dari teorisasi masyarakat setempat. Dawam Rahardjo, "Ilmu Sejarah Profetik dan Analisis Transformasi Masyarakat," Kuntowijoyo, Paradigma Islam: Interpretasi untuk Aksi (Bandung: Mizan, 1991), h. 14-15. 


\section{Muhammadiyah dalam Perspektif Praksis Sosial Kemanusiaan}

Banyak orang hanya mengingat ajaran KH. Ahmad Dahlan sebagai purifikasi atau pemurnian ajaran keagamaan. Tidak banyak yang menaruh perhatian pada kontribusi sosial atas berdirinya Muhammadiyah, sekitar tahun 1912-1914. Padahal, dalam banyak kesempatan, Muhammadiyah telah memberikan teladan untuk bersikap wajar terhadap agama, simbol agama, tradisi, bahkan kepercayaan setempat yang berbau mistis.

Pendirian Muhammadiyah pun terinspirasi dari organisasi Budi Utomo. Modernitas organisasi nasionalis ini menjadi contoh yang baik demi kemajuan Islam. Kendati mayoritas anggota-anggota Budi Utomo adalah Abangan yang tidak terlalu taat, bahkan acuh terhadap agama, namun ada sisi positif yang diapresiasi dengan baik oleh pendiri Muhammadiyah.

Bagi seorang pejuang Islam, mengikuti modernitas Budi Utomo, bukan berarti harus mengikuti pemikiran dan praktik beragama para anggotanya. Dari sinilah, akhirnya pada 20 Desember 1912, Muhammadiyah mengajukan diri sebagai organisasi resmi yang diakui oleh Belanda. ${ }^{18}$ Pendirian persyarikatan memang diniatkan untuk ibadah dan demi kemaslahatan umat. Hal ini adalah urusan dunia dan sama sekali bukan urusan ibadah, terlebih ibadah mahdhah (khusus).

Di lain kesempatan, pendirian sekolah Muhammadiyah sangat terinspirasi oleh berdirinya sekolah Belanda, yang memiliki agama resmi Kristen. H.I.S. met de Koran jelas meniru H.I.S. met de Bibel. ${ }^{19}$ Bukan hanya itu, kegiatan-kegiatan sosial oleh umat Kristiani seperti pelayanan kesehatan dan poliklinik, juga menjadi inspirasi. Hal ini bukan dimaksudkan untuk Kristenisasi dalam tubuh persyarikatan. Sikap sekular yang proporsional, menjadikan Muhammadiyah lebih peka secara sosial, tanpa harus mengadopsi praktik keagamaan an sich.

Di tengah ikhtiar untuk kebangkitan umat Islam, Dahlan tidak jarang mendapat hujatan dari banyak pihak. Termasuk di antaranya, secara sepihak ia dianggap kafir oleh para agamawan saat itu. Bagi mereka, bukanlah hal yang patut bagi kaum Muslimin, untuk mengikuti Belanda atau agama lain. Sembari bersenjata legitimasi hadits nabi, "Barangsiapa mengikuti suatu kaum, maka ia bagian dari kaum itu," golongan agamawan menisbatkan sandangan "kafir” bagi

Alfian, Politik Kaum Modernis, Perlawanan Muhammadiyah terhadap Kolonial Belanda (Jakarta: al-Wasath Publising Press, 2010), h. 168.

19 Alfian, Politik Kaum Modernis, h. 165. 
pendiri Muhammadiyah tersebut. Kendatipun, sebenarnya mereka secara tidak adil menerapkan standar agama untuk mengklaim kebenaran tertentu. Karena sementara di lain kesempatan, mereka melestarikan agama yang feodal. Dengan kata lain, sangat menjunjung agama dan kultur yang mengekang. Otoritas keagamaan dan rahmat Tuhan, hanya berlaku bagi para bangsawan, agamawan dan keturunannya. Itulah orang-orang titisan ilahi. Agama dalam konteks ini, tidak egaliter dan hanya memihak kelas sosial yang lebih tinggi dari padanya.

Persoalannya bahwa, Islam menurut pemegang jabatan Kyai Penghulu ini merupakan agama yang egaliter, menjunjung kemanusiaan dan membebaskan umat dari pelbagai mistis. Sejarawan Kuntowijoyo membenarkan hal ini. Menurutnya, menjelang berdirinya Kweekschool, Dahlan terlibat secara intensif atas misi kemanusiaan tersebut. Ia ber-tabligh dengan mengunjungi muridmuridnya. Menurut sudut pandang masyarakat, guru mencari murid adalah aib sosial budaya. Sebagai Khatib Mesjid Besar dan Ketua Hoofdbestuur Muhammadiyah, tidak sepantasnya berlaku demikian. Ada dua implikasi atas sikap Dahlan, yaitu: Pertama, ia membongkar idolatry atau pemujaan tokoh ulama. Kedua, ia membumikan ajaran agama yang nampak melangit, hingga menjadi kamanungsan. ${ }^{20}$ Inilah yang disebut dengan demistifikasi agama. Dengan kata lain, ada semacam upaya sekularisasi terhadap paham keagamaan di kala itu.

Teranglah bahwa, kembali kepada kitab suci bukan bermaksud untuk menyerahkan semuanya kepada teks keagamaan (scripturalism). Upaya kembali, merupakan usaha pragmatis, untuk kemajuan umat yang telah lama terpenjara. Masyarakat Islam secara sosial telah menanggung derita kolonialisme dan imperialisme. Sementara di sisi lain, feodalisme dan sistem sosio-religious menggenapi kekangan yang ada. Orang-orang miskin, harus tunduk pada pemuka agama dan para bangsawan, tanpa bisa secara manusiawi untuk memanfaatkan rasionalitas mereka.

\section{Gerakan Muhammadiyah, Gerakan Sosial Profetik}

Ciri pembebasan, sekularisasi dan demistifikasi, adalah ciri utama dari profetisme. Dahlan secara total, mengabdi untuk misi kenabian ini. Seperti halnya rasul, banyak tantangan yang dihadapi. Tidak jarang pula mengancam jiwanya, karena mendobrak tradisi dan kekuasaan politik.

20 Kuntowijoyo, "Jalan Baru Muhammadiyah," h. xiii-xiv. 
Rasul sangat dibenci oleh kaum kafir Quraisy, bukan sekedar karena membawa agama baru. Liberasi dengan cara menggulirkan politik zakat, ${ }^{21}$ adalah alasan utamanya. Jika sebelumnya orang miskin membayar pajak pada orangorang kaya, bangsawan dan pemimpin keagamaan, - yang mana hal ini di dukung oleh kondisi sosio-kultural dan religius - maka kehadiran rasul merupakan pembongkaran terhadap tradisi dan menerapkan tradisi baru yang lebih humanis. Hal yang sama dilakukan oleh Dahlan. Tatkala umat sebagai pribumi yang miskin tidak boleh bersekolah dan paham keagamaan hanya didominasi oleh para ahli dan bangsawan, maka ia mempertaruhkan hidupnya untuk kebebasan pendidikan.

Profetisme termasifestasikan menjadi lembaga sosio-religius yang berupa sekolah, poliklinik (saat itu PKO atau Penolong Kesengsaraan Oemat) dan panti asuhan. Dewasa ini, menurut Pusat Data Muhammadiyah, secara mengejutkan Muhammadiyah mencatatkan angka 10314 lembaga pendidikan. Kuantitas spektakuler itu, secara rinci terdiri dari TK/TPQ (4623); SD/MI (2604); SMP/ MTs (1772); SMA/SMK/MA (1143); PT (172)22. Atas kemajuan yang diraih, tidak heran bila dunia internasional, mengakui Muhammadiyah sebagai organisasi keagamaan terbesar yang memiliki lembaga pendidikan terbanyak di dunia. ${ }^{23}$

Perkembangan Muhammadiyah di bidang pendidikan ini, secara fundamental memiliki peran strategis bagi masyarakat. Sebagai organisasi dakwah, secara leluasa dapat melakukan desaminasi profetisme Islam. Dakwah ini bukan hanya dalam bidang peribadatan, namun juga bertanggungjawab atas masa depan umat secara sosial. Secara teologis, Muhammadiyah menghendaki berfungsinya agama secara pragmatis, untuk kemaslahatan umatnya, baik di dunia maupun di akhirat. $^{24}$

Hal yang sama disuarakan oleh Syamsul Arifin bahwa, peran penting pendidikan Muhammadiyah, membawa kepada dua hal. Pertama, atas ajaran

21 Kuntowijoyo, "Islam dan Kelas Sosial: Upaya Konseptualisasi," Paradigma Islam: Interpretasi untuk Aksi (Bandung: Mizan, 1991), h. 300.

22 http://mdc.umm.ac.id/ (diakses pada 9 Maret 2012).

23 Komentar ini merupakan pidato Abdul Mu'ti dalam acara Rapat Kerja Pimpinan Wilayah Muhammadiyah Jawa Barat. Lihat Roni Tabrani, "Muhammadiyah Harus Melakukan Akselerasi," http://www.muhammadiyah.or.id/id/news-832-detail-muhammadiyah-harus-melakukan-akselerasi.html (diakses pada 9 Maret 2012).

24 Asjmuni Abdurrahman, Manhaj Tarjih Muhammadiyah, Metodologi dan Aplikasi (Yogyakarta: Aditya Media dan PSIK Universitas Muhammadiyah Malang, 2000), h. 31-41. 
kenabian yang dimiliki, Muhammadiyah berkesempatan untuk membentuk paradigma berpikir umat. Kedua, Muhammadiyah memberikan kontribusi yang besar bagi mobilitas sosial. ${ }^{25}$

Di usia yang genap satu abad, jangkauan ikhtiar sosial Muhammadiyah semakin besar dan luas. Universitas Muhammadiyah Malang misalnya, pada 2012 dengan percaya diri mengumandangkan motto, "Dari Muhammadiyah untuk Bangsa." Jika diamati dengan baik, maka kiprah pendidikan Muhammadiyah, turut memberikan makna yang mendalam pada ruang kehidupan kebangsaan.

Inilah yang membuat organisasi keagamaan ini bertahan cukup lama. Paling tidak, dapat disandarkan pada tiga sebab utama, yaitu: pertama adalah Muhammadiyah tetap bertahan karena secara teologis, mengakomodir paradigma kenabian (profetisme) dalam jejak langkahnya; kedua, prinsip etis ber-Islam dan berorganisasi adalah semata-mata menaruh kepedulian pada persoalan kemanusiaan dan transformasi sosial; sedangkan yang ketiga, strategi gerakan Muhammadiyah adalah gerakan kebudayaan, baik itu dikenal sebagai gerakan dakwah dan gerakan pendidikan.

\section{Profetisme, Muhammadiyah dan Gelombang Besar Globalisasi}

Sementara di pihak lain dalam arus sejarah, lambat laun profetisme diartikan terlampau birokratif dan tidak mencapai maksud yang sebenarnya. Sebenarnya masalah ini tidak terlalu jelas untuk disaksikan secara sederhana. Situasi dunia dan kehidupan kontemporer, membuat segala dimensi sosial menjadi lebih rumit. Gelombang besar globalisasi adalah tantangan yang sangat berat bagi Muhammadiyah, khususnya pendidikan Muhammadiyah. Namun paling tidak, segala faktor penyebab terjadinya kaburnya segala pesan agama, bisa ditelusuri dalam beberapa aspek, misalnya ekonomi, politik, sosial, agama dan kebudayaan.

\section{Gelombang Neo-Liberalisme Ekonomi}

Pertama, dalam bidang ekonomi, zaman tidak lagi dikendalikan oleh dua kubu ekstrim ideologi yang mengatur sistem ekonomi dunia. Amerika yang kapitalis dan Uni Soviet atau Rusia yang sosialis, bukanlah rujukan segala problem keuangan yang mendikte seluruh belahan dunia. Kini, hanya ada satu

25 Syamsul Arifin, Al-Islam dan Kemuhammadiyahan (AIK) sebagai Basis Pendidikan Nilai (Makalah Seminar Pekerti di Universitas Muhammadiyah Malang, 8-9 Februari 2012), h. 2. 
penguasa adidaya, yaitu kapitalisme. Namun tepatnya kapitalisme baru atau neokapitalisme. ${ }^{26}$

Neo-kapitalisme ini tidak dikuasai oleh satu negara terbesar di dunia dengan segala kekuasaannya, yang dalam hal ini, negara dimaksud adalah Amerika Serikat. Mungkin situasi geografis dan sosiologis yang telah mendukung AS sebagai tempat pertemuan pelbagai perdagangan dan transaksi ekonomi dunia, yang menjadi alasannya. AS sebagai melting pot, yang melindungi ratusan korporasi internasional, yang mengendalikan pasar saham dunia. ${ }^{27}$

Segala kebijakan AS, maupun kebijakan dunia, berkiblat pada kepentingan akumulasi profit pelbagai korporasi ini. ${ }^{28}$ Akses internasional yang menembus segala batas, kemudahan transportasi, telekomunikasi, persentuhan lintas budaya, dan seluruh hal yang berhubungan dengan sosial kemanusiaan, senantiasa melayani kepentingan tersebut. Kondisi yang dialami secara massal ini disebut dengan globalisasi.

Globalisasi menjadi sarana yang hanya menguntungkan beberapa pihak, antara lain: negara adidaya, korporasi internasional, pemilik modal, pemilik kebijakan dunia, penguasa militer internasional dan pengendali intelejen yang mampu mengintai segala informasi apapun yang dibutuhkan demi keberlangsungan pragmatis, kapitalisme. Globalisasi, di luar perspektif alamiah, adalah ruang sosial sebagai bentukan kapitalisme dan berjalannya proses kapitalisasi.

Apakah hal ini memiliki titik temu secara langsung pada rigiditas profetisme dalam kubu Muhammadiyah? Tidak hanya persyarikatan yang berkhidmat untuk membela orang miskin saja yang mengalami pergeseran paradigma sosial, namun seluruh belahan dunia, terlebih negara dunia ketiga mengalami nasib yang kurang baik karena tidak bisa mengendalikan apa pun dari gerak pasar makro dunia.

26 Ilustrasi Joseph S. Nye, Jr., - seorang dekan dari the Kennedy School of Government, Universitas Harvard yang juga Ketua Dewan Intelijen Nasional dan Asisten Menteri Pertahanan Amerika Serikat era Bill Clinton - tentang neo-kapitalisme sangat terus terang, tatkala mengritik negaranya sendiri yang berperan sebagai penguasa tunggal kapitalisme dunia. Lihat Joseph S. Nye, Jr., "The American Colossus," The Paradox of American Power: Why the World's Only Superpower Can't Go It Alone (New York: Oxford University Press, 2003), hal 1-40. Lihat juga keseluruhan analisis tajam oleh Amien Rais, Agenda Mendesak Bangsa, Selamatkan Indonesia (Yogyakarta: PPSK Press, 2008).

27 Charles Hirschman, "America's Melting Pot Reconsidered," JSTOR: Annual Review of Sociology, Vol. 9, (1983), h. 397-423.

28 Samuel Bowles, David M. Gordon dan Thomas E. Weisskopf, "Power and Profits: The Social Structure of Accumulation and the Profitability of the Postwar U.S. Economy," Sage Journals: Review 
Aspek hidupan sosial seperti pendidikan, tidak penting memiliki tujuan luhur demi mencerdaskan kehidupan bangsa. Karena senyatanya, moda ekonomi-lah yang mengendalikannya. Pendidikan yang mengindahkan segala petunjuk kepentingan "pasar" yang lebih didengar, mendapat kesempatan untuk terus bertahan hidup dan dilindungi oleh pelbagai legislasi oleh negara yang tidak berdaya.

Tidak perlu sakit hati jika ada sindiran bahwa, "UMM bukan lagi Universitas Muhammadiyah Malang, namun Universitas Makin Mahal."29 Memang senyatanya, untuk memberikan yang terbaik untuk bangsa, termasuk orang miskin, memerlukan fasilitas yang terbaik, yang tidak mungkin dicapai dengan harga murah.

Sementara jika tidak cerdik memainkan strategi pemasaran pendidikan tinggi, maka peringkat dunia pun tidak mungkin akan diraih. Padahal dengan tidak terbantahkan bahwa ranking dunia adalah berkah dari segala ketaatan terhadap sistem pasar. Gaya pasar adalah trend yang membuat seluruh umat manusia menjadi bangga karenanya. ${ }^{30}$

Ironis memang, jika pada kelahirannya Kyai Dahlan mendirikan pelbagai lembaga sosial kemasyarakat dengan nama "amal usaha", kemudian dalam situasi yang sangat rumit ini, kiranya lebih cocok disebut sebagai "usaha amal". Maka lembaga filantropis yang dibicarakan di dunia, tidak sepenuhnya benar, karena berpotensi pula dalam gerak kapitalisasi lembaga amal.

Kualitas riset mutakhir, kampus yang terakreditasi, dosen yang bersertifikat, fasilitas yang lengkap, jaringan internasional yang kuat dan penyelenggaraan pendidikan yang berkualitas, harus dibayar dengan harga yang sangat mahal. Mengambil jarak dari sistem pasar, apalagi berusaha melawan, berarti bunuh diri dan menjerumuskan pada jurang kehancuran. Jika universitas tidak memberikan lehernya pada aturan kapitalisme, maka jelas dengan senang hati akan mempersilahkan rakyat untuk bersekolah dengan harga murah, bisa diakses oleh mayoritas orang miskin, beasiswa yang melimpah, dan dengan demikian,

of Radical Political Economics, Vol. 18, No. 1-2 (SPRING \& SUMMER 1986), hal 132-167. Lihat juga Greta R. Krippner, "The financialization of the American economy," Oxford Journals of Economics $\mathcal{E}^{2}$ Social Sciences, Socio-Economic Review, Vol. 3, Issue 2, (2005), h. 173-208.

29 Auto kritik datang dari Lutfi J. Kurniawan dalam kuliahnya pada "Sekolah Filsafat II: Poskolonialisme dan Syed Hussein Alatas,” Pusat Studi Islam dan Filsafat (PSIF) Universitas Muhammadiyah Malang pada 15 Juli 2011 di Malang.

30 Hasnan Bachtiar, "Menggugat Ekonomisme Pendidikan," Social Critiques and Commentaries (Singapore: Leftwrite Center and the Reading Group of Singapore, 2011). 
kebangkrutan akan menghunjamkan belati pada amal usaha yang telah lama dibangun dan dibesarkan.

Lalu di mana profetisme berada? Dalam pertanyaan yang lebih jujur dan sarkartis adalah, di mana profetisme bersembunyi? Ia bersembunyi dibalik teks dan kredo yang hanya layak untuk dinyanyikan secara merdu, jangan sampai dilaksanakan. Memang tidak banyak hal yang bisa dilakukan. Sama sekali tidak ada jalan yang mudah untuk melewati segala kesukaran ini, namun bukan berarti tidak ada jalan keluar. Karena itu, hal sekecil apapun, akan diupayakan walau hanya sedikit memberi harapan.

\section{Politik Partitokrasi dan Imperialisme Lokal}

Kedua, dalam bidang politik, profetisme jelas mengalami redup yang berkepanjangan, khususnya pada sektor pendidikan tinggi. Adakah universitas yang benar-benar membela rakyat kecil? Hanya publik yang memiliki kaca mata genealogis dan kecurigaan yang tulus yang bisa mengungkap semuanya. Subyektifitas kampus telah sekian lama bergelora dengan terang atau secara sembunyi untuk mendukung kepentingan tertentu. Tidak perlu lagi malu untuk menyebut istilah "mafia Berkeley"31, "penjahat kerah putih"32, "pseudo intellectual" 33 , "ilmuwan menara gading ${ }^{34 "}$ dan bahkan "para tukang tenung seperti dalam kisah nabi-nabi”. Sederet julukan kasar itu, mereka lahir dan beristirahat dengan nyaman di universitas.

Di luar konteks masalah besar hubungan politik dengan universitas, atau keberpihakan politik universitas terhadap kelompok politik tertentu, situasi politik nasional dan global telah turut memperkeruh masalah kemanusiaan yang paling fundamental.

Indonesia sendiri belakangan tengah dilanda partitokrasi. ${ }^{35}$ Ini adalah kondisi

31 David Ransom, Mafia Berkeley dan Pembunuhan Massal di Indonesia (Jakarta: Koalisi Anti Utang, 2006).

32 Istilah ini dipopulerkan oleh Edwin Sutherland, seorang kriminolog dan sosiolog terkemuka di Amerika Serikat. Lihat J. Kelly Strader, "The Judicial Politics of White Collar Crime," 50 Hastings L. Rev. 1199, (1999), h. 1204-14.

33 Amien Rais, Agenda Mendesak Bangsa, Selamatkan Indonesia (Yogyakarta: PPSK Press, 2008), h. 107-108; $127-137$.

34 Julien Benda, Pengkhianatan Kaum Cendekiawan (Jakarta: Gramedia Pustaka Utama, 1997).

35 Istilah partitokrasi ini di Indonesia, dipopularkan oleh J. Kristiadi, "Menuju Negara Partitokrasi," Kompas, Selasa, 11 Oktober 2011. Lihat juga Jean Blondel, "Party government, patronage and party decline in Western Europe," R. Gunther, J Montero and J Linz (eds.), Political Parties: Old Concepts and New Challenges (Oxford: Oxford University Press, 2002), h. 233-257. 
di mana partai yang lebih berkuasa dari pada penguasa yang sebenarnya, pemilik kebijakan atau pemerintah. Akibatnya, segala keputusan politik yang berhubungan dengan hajat hidup orang banyak, tidak banyak disinggung, bahkan menjadi hal yang sama sekali tidak penting. Di lain pihak, kebijakan publik yang berhubungan dengan kepentingan dan keberlangsungan beberapa pihak, khususnya kepartaian, itulah agenda utama "berbangsa dan bernegara". Demokrasi hanyalah ucapan, sekiranya orang waras tidak menyebut bahwa kita masih belajar tentangnya. Korupsi, kolusi dan nepotisme menjadi tren yang tidak kalah mentereng dengan sandangan istilah "selebritis" pada artis-artis. Negara ini menjadi negara yang mungkin, "layak untuk gagal."

Tidak ada negara yang sebenarnya, tidak ada pula pemerintah dan wakil rakyat, serta rakyat itu sendiri. Yang ada adalah negara adalah lahan bisnis bagi politisi untuk meraih uang, pangkat, jabatan, kuasa, segala yang diinginkannya yang berhubungan dengan kepuasan duniawi. Negara untuk keadilan dan kesejahteraan rakyat yang terkendali di tangan rakyat sendiri, hanyalah isapan jempol. Ada wakil rakyat yang tidak punya rakyat. Sejalan dengan sisi lainnya, ada rakyat yang tidak pernah punya wakil. ${ }^{36}$

Pemilu atau electoral politics adalah ide yang sangat masuk akal untuk jalan pintas meraih apa yang diinginkan oleh individu, maupun sekelompok orang yang memiliki kapital. Wakil rakyat dengan sangat mudah dan legal membeli suara rakyat. Demikian juga dengan rakyat, tidak pernah merasa memiliki wakil karena memang secara kutural dan struktural, mereka sedang ditimpa kemiskinan yang sangat berat. Dengan demikian, rakyat hanya perlu uang, untuk kesejahteraan sepintas dan semu yang dibayar dengan harga mahal, beberapa periode kesengsaraan akibat garis pemerintahan yang dipimpin oleh mereka yang terburuk sepanjang sejarah umat manusia.

Apa yang bisa diperbuat oleh universitas menanggapi hal ini? Hanya ada dua hal yang paling mungkin, dan sebenarnya hal ini dapat dibuktikan kapan saja, yaitu yang pertama, mencoba memperbaiki keadaan, sedang yang kedua, menikmati hasil dari upaya pragmatis dan oportunis dari segala kebusukan politik kebangsaan.

Demontrasi tidak akan pernah memberikan pengaruh apapun untuk merubah kebijakan publik apapun yang merugikan rakyat. Demontrasi yang sejatinya

Moeslim Abdurrahman, "Politik Umat, Politik Pemberdayaan," Ajang Budiman dan Pradana Boy ZTF. (eds.), Menggugat Modernitas Muhammadiyah. Refleksi Satu Abad Perjalanan Muhammadiyah (Jakarta: Best Media Utama dan Pusat Studi Islam dan Filsafat UMM, 2010), h. 54-56. 
menghantarkan simbol sosial yang berupa kritik bagi pemerintah, hanyalah menjadi seremonial yang penuh pura-pura dan bahkan alat politik yang tidak kalah keji dengan segala agenda pragmatisme yang diinginkan. Bahkan, siapapun akan tertawa bagi mereka yang menyaksikan bahwa ada demontrasi yang dilakukan mahasiswa demi hanya untuk sesuap nasi, atau bayaran yang murah, meskipun beresiko mengorbankan nyawa mereka di tangan peluru para preman pemerintah atau polisi atau militer yang tidak bertanggungjawab.

Situasi yang sangat rumit ini, sukar dikendalikan. Kendati diskursus publik senantiasa mengumandangkan demokrasi sebagai resep kemajuan, hal ini tidak pernah dilaksanakan dengan benar oleh seluruh pihak di Indonesia. Para pembaca demokrasi dunia akan terkejut menyaksikan seluruh tesis ahli demokrasi, Robert Dahl, termentahkan begitu saja di negeri ini. Demokrasi yang sejatinya menghindari adanya kelaliman pemerintah yang berkuasa, kini hanya dengan mudah segala celah administrasi legal untuk kepentingan kelompok penguasa. ${ }^{37}$ Politik pendidikan dan pendidikan untuk politik kebangsaan, tidak memiliki tempat yang relevan bagi kepentingan kekuasaan. Demikianlah keprihatinan yang mendalam yang sedang dialami negeri ini.

\section{Disfungsi Sosial Agama}

Ketiga, tengah terjadi disfungsi sosial terhadap agama. Artinya, agama menjadi tidak populer, atau paling tidak, menjadi manipulatif, karena kondisi sosial yang serba sulit, tampak tidak ada jalan keluar dan terlampau banyak tekanan, baik secara kultural maupun struktural. Agama tidak lagi seperti yang diharapkan seperti spirit kelahirannya (agama otentik), yaitu menekankan pada praksis pemerdekaan sosial.

Di satu sisi bisa dikatakan bahwa, pelbagai tekanan akan menciptakan struktur masyarakat yang optimis dan penuh keberanian dalam meyelesaikan masalahnya sendiri. Namun di sisi lain, kekerasan dan tribalitas akan menjadi situasi yang lazim. Contoh yang paling jernih untuk menggambarkan hal ini adalah bidang pendidikan. Pendidikan dan lembaga pendidikan memang menyisakan harapan untuk membentuk dan membangun karakter anak bangsa yang beradab dan bermartabat. Namun di lain pihak, tidak jarang bahwa pendidikan hanya menjadi "jembatan bagi tercapainya hajat hidup primer bagi pekerja pendidikan”. Dengan kata lain, pendidikan adalah proyek bisnis, baik

37 Robert Dahl, "Why Democracy?,” On Democracy (New Haven: Yale University Press, 1998), h. 46. 
itu oleh pemilik modal maupun pekerja, yang mengabaikan tugas utama mencerdaskan kehidupan bangsa. Penulis menyebut adanya pembentukan budaya tribal, karena "kerusakan kebudayaan" (pendidikan), akan jauh memberikan dampak yang negatif dari pada tribalitas dalam pengertian yang sebenarnya.

Tidak ada satu pihak pun yang patut disalahkan dalam segala tekanan sosial ini. Di tengah kendali hebat oleh struktur sosial, proses pendidikan adalah lahan pelampiasan kemarahan struktural, baik untuk pemenuhan segala hajat hidup ekonomi maupun untuk kepentingan sosial lainnya. ${ }^{38}$ Dalam konteks ini, agama bukanlah apapun. Agama dapat pula dimanfaatkan sebagai jalan untuk pelampiasan hasrat struktural, sama halnya dengan pendidikan. Komodifikasi agama atau upaya pragmatis dan oportunis berlabel agama, adalah contoh yang paling mudah disaksikan di mana-mana. Akibatnya, terjadilah kebodohan massal, keberlakuan kebudayaan mekanik yang alpa moralitas kemanusiaan, kemiskinan, meningkatnya kriminalitas dan kerap meletus konflik komunal di antara masyarakat. Agama benar-benar menjadi nilai etis yang beku dan tidak berdaya di hadapan struktur sosial yang pelik.

Profetisme yang berciri pemerdekaan sosial, tidak pernah terimplementasi dengan baik. Memang ada beberapa lembaga sosial, seperti Lembaga Swadaya Masyarakat atau Organisasi Kemasyarakatan yang melakukan upaya tertentu demi membebaskan rakyat dari pelbagai belenggu sosial. Mereka biasanya merupakan gerakan-gerakan non-parlementer yang berusaha membuat rekayasa sistem sosial, agar masyarakat mampu bangkit dengan sendirinya. 39

Namun sayangnya, untuk mencari titik temu antara gerakan sosial untuk pemerdekaan sosial, dengan proses pendidikan tinggi dan profetisme, bukanlah

38 Ellen Kristi menegaskan bahwa, kerap kali anak manusia sebagai peserta didik, hanya menjadi korban dari komersialisasi pendidikan. Karena itu, tidak sepantasnya orang tua menyerahkan begitu saja nasib dan masa depan anak-anak di hadapan komodifikasi pendidikan, sistem kapitalistik dan tata aturan pasar. Lihat Ellen Kristi, Cinta yang Berpikir: Sebuah Manual Pendidikan Karakter Charlotte Mason (Semarang: Ein Institute, 2012), hal. 31. Paulo Freire, secara kritis memberikan penilaian yang sama. Kultur kapitalistik cenderung membentuk mental para peserta didik untuk berwatak eksploitatif dan despotis. Karena itu, tidak jarang bahwa peserta didik dianggap sebagai sekedar wadah (benda), tempat menabung pengetahuan. Paulo Freire, Pedagogy of the Oppressed (New York: the Continuum International Publishing Group Inc., 2000), hal. 71. Dalam konteks Indonesia, narasi kapitalisasi pendidikan ini dikritik secara keras oleh Sarbiran, "Pendidikan Islam dan Tantangan Globalisasi Ditinjau dari Aspek Ekonomi dan Politik,” dalam Imam Machali dan Musthofa (eds.), Pendidikan Islam dan Tantangan Globalisasi. Buah Pikiran seputar Filsafat, Politik, Ekonomi, Sosial dan Budaya (Yogyakarta: Ar-Ruzz Media, 2004), hal. 24-47.

39 Mansour Fakih, The Role of Non-governmental Organizations in Social Transformation: A Participatory Inquiry in Indonesia (Dissertation in the University of Massachusetts at Amherst, 1995). 
hal yang sederhana. Idealnya universitas yang menjunjung spirit profetisme, mampu memberikan alokasi dana dan pelbagai arahan kebijakan pendidikan untuk membela kelas tertindas. Dengan demikian, bukan tidak mungkin pihak universitas menyelenggarakan kerjasama dengan pelbagai organisasi non pemerintah, untuk meningkatkan kesejahteraan sosial dan melakukan advokasi politik terhadap golongan bawah (grass root).

Yang menjadi masalah adalah, untuk menjaga keberlangsungan sistem ekonomi universitas (sustaintabilitas), maka prioritas utama adalah kendali akumulasi profit di hadapan gelombang pasar, bukan pemerdekaan sosial. Tidak heran jika dengan demikian, kesibukan sehari-hari menumbuhsuburkan birokratisasi segala kegiatan pendidikan dan kependidikan, termasuk pula pengajaran etika profetik di universitas.

Dari seluruh kerumitan sebagai sajian utama kondisi keseharian bangsa, maka dapat dimengerti bahwa struktur dan kelas sosial, begitu berpengaruh terhadap redupnya peran pemerdekaan sosial dari spirit keagamaan. Kelas menengah intelektual sebagaimana halnya para civitas akademia, hanyalah masyarakat biasa, yang kendati secara struktural semestinya mampu menjadi fasilitator bagi perubahan sosial, namun secara kultural tidak berdaya di hadapan kebudayaan mekanik, sehingga tradisi birokratif bukan menunjukkan keunggulan manajemen yang baik, justru sebaliknya, sebagai belenggu kemajuan dan mobilitas sosial.

\section{Kematian (Pendidikan) Agama}

Keempat, adanya fenomena kematian (pendidikan) agama. Agama sebagai suatu doktrin, sementara ini tidak pernah dipahami sebagai hal yang potensional untuk transformasi sosial. Pelbagai aspek pendidikan Islam (tarbiyah Islamiyah) seperti akidah, tauhid dan iman, hanya merupakan sederet etika kognitif atau paling tidak hanya sebagai aspek penting untuk pembangunan karakter individual, yang tidak menekankan aspek komunal dan kemasyarakatan yang sedang ditimpa keprihatinan sosial. ${ }^{40}$

Agama dalam hal ini, hanyalah spiritualitas yang menekankan aspek ritualitas semata. Agama bukanlah alat yang membumi, apalagi sebagai misi suci untuk kesejahteraan dan keadilan umat manusia. Agama adalah seperangkat aturan

40 Yang terparah kini tauhid pun dijadikan sebagai komoditas yang mendukung akumulasi profit para pemilik modal. Lihat Eko Prasetyo, Astagfirullah: Islam Jangan Dijual (Yogyakarta: Resist Book, 2007). 
ketat dari langit, yang tidak pernah menyentuh aspek kemanusiaan. Yang terparah, agama adalah teks yang mampu menyelesaikan atau dipaksa menyelesaikan problem kompleks kemanusiaan yang tidak terbendung perkembangannya. Pelanggaran terhadap teks, jelas akan disinyalir sebagai kafir karena melanggar syariat atau garis hukum agama yang telah lama ditetapkan oleh ketetapan langit.

Dari waktu ke waktu, model agama yang seperti inilah yang diajarkan pada generasi, ke generasi berikutnya. Dengan demikian, agama tidak terlalu berhubungan dengan kemiskinan, kebodohan massal, atau fenomena sosial lainnya. Praktik pendidikan di pelbagai tempat, termasuk pendidikan tinggi, hanyalah formalitas yang mendukung segala titah dari langit. Atau sebenarnya, inilah kegagalan manusia dalam menangkap wahyu ilahi, karena terlampau menitikberatkan dengan segala keyakinan bahkan ideologi terhadap sisi sakralitas agama, sementara segala hal yang berhubungan dengan akal dan fenomena sosial historis terabaikan.

Beberapa pengamat sosial keagamaan menyebut gejala ini sebagai kematian agama. Bukan agama itu sendiri yang mati, namun manusia atau para pemimpin keagamaan, gagal menafsirkan pesan langit yang sebenarnya justru memihak orang-orang miskin dan kelas tertindas. ${ }^{41}$

Ada beberapa tipe kegagalan manifestasi nilai agama dalam ruang publik. Yang pertama adalah yang tidak memiliki perangkat yang cukup untuk menemukan akar masalah sekaligus solusi bagi relasi agama dan problem sosial kekinian; yang kedua adalah mereka yang mengerti hermeneutika pembebasan, namun sama sekali tidak tertarik dalam upaya pemerdekaan sosial itu sendiri; yang ketiga adalah mereka yang Islamis, namun bagi mereka agama adalah teks keagamaan itu sendiri, yang tercerabut akar inter-kontekstualitasnya dari kehidupan nyata lintas historis; yang keempat adalah mereka yang tidak tahu menahu tentang agama, bahkan tidak memiliki kepedulian terhadapnya.

Alasan ini sangat masuk akal untuk menjelaskan kegagalan relasi agama dan perubahan sosial. Dalam sudut pandang antropologis, seluruh manusia memiliki

41 Wacana ini seperti yang dibicarakan oleh Nur Khalik Ridwan, Islam Borjuis dan Islam Proletar: Konstruksi Baru Masyarakat Islam Indonesia (Yogyakarta: Galan Press, 2002). Wacana lebih tajam lainnya, ditulis oleh Sumanto al-Qurtuby, Lubang Hitam Agama: Mengkritik Fundamentalisme Agama, Menggugat Islam Tunggal (Jakarta: Rumah Kata, 2005). Namun, untuk menemukan substansi gagasan inti dari uraian berikut, silahkan merujuk pada Moeslim Abdurrahman, Islam Transformatif (Jakarta: Pustaka Firdaus, 1997). Lihat juga Azhar Ibrahim Alwee, "The Making of Progressive Religion," Islam, Religion and Progress, Critical Perspective (Singapore: the Reading Group, 2006). 
kepentingannya masing-masing, yang sangat mendasar. Perspektif hidup setiap manusia, memiliki hubungan yang erat dengan hasrat yang ia miliki. Sementara bahwa, hasrat atau dalam bahasa agama adalah "niat" setiap manusia, hendak diarahkan untuk melayani siapa?

Ada benarnya Clifford Geertz yang memberi pengertian bahwa manusia melihat realitas selalu dibalik tirai. ${ }^{42}$ Tidak pernah ada seorang pun yang menatap dan menilai kebenaran dengan mata telanjang. Selalu ada simbol dan di balik simbol selalu ada tendensi tertentu yang menjamin penentuan sikap untuk memutuskan, apa yang dipresepsi oleh manusia. Singkat kata, jika dalam sistem simbol ini tidak pernah menerima, merenungkan dan menaruh perhatian yang penuh pada nilai etis agama yang universal, maka seperti pada istilah semantis agama itu sendiri, akan berubah menjadi gama, atau kekacauan.

Dalam perspektif religio-naturalis, bumi yang dihamparkan oleh Tuhan kepada manusia, sama sekali bukan untuk Tuhan itu sendiri. Sepenuhnya telah menjadi milik manusia. Secara moral, kepemilikan akan hak kebumian ini, telah dibagi secara adil dan rata atau setimbang. Dengan demikian, pelayanan terhadap segala rahmat Tuhan, adalah dengan mewujudkan rasa cinta kasih dan pemeliharaan bumi itu sendiri. Bumi dan semesta adalah simbol eksistensi Ilahi yang harus diapresiasi melalui hubungan antara manusia dengan manusia, maupun manusia dengan alam.

Sayang sekali, syahwat kemanusiaan kadang tidak pernah menghendaki falsafah kepemimpinan manusia di bumi sebagai wakil Tuhan. Gejolak pragmatisme sempit untuk melayani nafsu birahi, kekuasaan, pamor, citra, pengakuan, kekayaan dan prestis, lebih menonjol dari pada segala niat mulia dari nilai universal agama.

Maka tidak perlu terkejut misalnya para pengamat menyadari bahwa, apa yang disebut sebagai agamawan Muslim atau ustadz, bukanlah sama sekali sebagai seorang alim yang hendak menerjemahkan pesan agama untuk masyarakat luas. Ustadz bukanlah hermes yang memiliki peran penting di hadapan agama dan perubahan sosial. Ustadz adalah sebuah profesi yang harus melayani kepentingan akumulasi kapital.

Melalui banyak media komunikasi, yang disebut dengan ustadz adalah mereka yang memiliki wajah cukup tampan, berjenggot dan berkumis tipis, bisa

42 Clifford Geertz, The Interpretation of Cultures (New York: Basic Book, 1977). 
mengaji dengan baik, berjaket kulit, memiliki mobil mewah, bahkan memiliki istri lebih dari satu, yang jelas segala abilitas yang dimiliki ustadz ini harus bisa dikomersialisasikan. Pendidikan agama dan transformasi nilai keagamaan itu sendiri, gagal seratus persen di hadapan ganasnya syahwat kapitalisme.

Di sisi lain, pengajaran agama tentang "hal yang tertinggi" dalam agama seperti tauhid, hanyalah upaya untuk memenuhi kebutuhan intelegensia individual. Tidak ada kaitannya dengan perubahan masyarakat yang menekankan kepedulian terhadap orang-orang miskin dan termarginalkan. Tauhid hanyalah pengetahuan tentang Tuhan yang sangat sederhana, bahkan memiliki lebih banyak larangan agar tidak menanyakan hal-hal yang tidak patut untuk ditanyakan, karena akan menejerumuskan kepada perilaku syirik, bid'ah, takhayul, khurafat atau dosa besar.

Namun sayang, makna-makna tentang dosa tersebut, sekali lagi, sangatlah sederhana. Apa yang diajarkan di sekolah dasar, tidak pernah berubah dengan apa yang diajarkan di perguruan tinggi. Padahal, pengabaian terhadap pokokpokok kepedulian sosial, sama halnya dengan dosa besar sosial. Inilah kegagalan hermeneutis yang tidak mampu menangkap adanya model syirik sosial, bid'ah sosial, takhayul sosial dan khurafat sosial. Semua itu adalah modifikasi dari segala model dosa sosial kontemporer yang baru bisa diidentifikasi dengan pelbagai pengetahuan sosial kritis, yang jarang dimiliki oleh agamawan Muslim dewasa ini.

\section{Pendidikan, Kebudayaan Islam dan Popularisme}

Kelima, popularisme tetap menjadi pekerjaan rumah yang cukup berat, bagi eksistensi agama atau lembaga keagamaan. Persoalan ini tentu saja merupakan persoalan kebudayaan. Kebudayaan adalah keseluruhan pandangan hidup manusia yang termanifestasikan dalam pengetahuan dan praktik hidup sehari-hari. Popularisme sebagai kebudayaan, adalah "trend" bagi sebagian besar orang, sehingga menjadi pandangan umum, termasuk memahami atas apa yang dimaksud dengan agama publik.

Paling tidak, ada dua arus besar popularisme ini. Yang pertama berafiliasi pada fundamentalisme keagamaan, sedangkan yang kedua merupakan kebudayaan yang dituntun oleh kekuatan pasar baru (pos-kapitalisme) dan globalisasi sebagai konstruksi neo-liberalisme. 
Arus yang pertama (fundamentalisme), barangkali lebih condong kepada perhatian yang besar pada persoalan ideologi dan pemahaman terhadap sejarah. Bagi golongan ini, Islam adalah agama yang otentik, sehingga keterikatan terhadap teks merupakan hal yang lebih utama dibandingkan dengan realitas keberagamaan (tekstualisasi). Ideologi Islam adalah harga mati, jika dihadapankan dengan banyak sekali ideologi-idelogi yang ada. Dalam memahami sejarah (historiografi), bagi mereka, sejarah sebagai pengetahuan dan spirit berkehidupan dimaknai sebagai ide dan imajinasi akan adanya masyarakat idaman yang terbaik. Tidak heran, untuk membuat legitimasi terhadap ideologi dan historiografi ini, maka para "Islamis" tersebut, menyandarkan diri pada tradisi Nabi bahwa, "Generasi terbaik adalah generasi awal masyarakat Islam." Dengan kata lain, persoalan popularisme adalah persoalan romantisme sejarah.

Lebih dari itu, pilihan untuk cenderung terhadap romantisme sejarah, bukan terjadi semena-mena tanpa sebab yang jelas. Ada faktor yang serius sebagai latar belakang yang menjadikan banyak komunitas memilih jalan hidup sebagai fundamentalis (salaf). Faktor yang paling masuk akal adalah respon terhadap modernitas, ${ }^{43}$ sedangkan yang lain adalah adanya peradaban Islam, khususnya peradaban teks dalam masyarakat Islam yang menyejarah.

Imperialisme, kolonialisme dan pelbagai intimidasi serta krisis kemanusiaan yang mengancam masyarakat Islam sebagai negeri jajahan, mampu membuat reaksi terhadap pemikiran keagamaan yang meluas dan merebak secara popular. Maka dalam hal ini, kehadiran popularisme-fundamentalisme Islam, bukan sekedar persoalan sosial kemanusiaan. Lebih dari itu, ini adalah persoalan identitas. Singkat kata, fundamentalisme, adalah ciri, simbol dan identitas umat Islam yang membedakan dari selainnya, khususnya imperialis, kolonialis dan para pendukungnya yang notabene adalah non-Muslim. ${ }^{44}$

Secara psikologis, reaksi ini lazim terjadi tatkala terjadi krisis sosial kemanusiaan di suatu wilayah, karena ekspansi fisik, intelektual dan kebudayaan oleh peradaban lain. Kendati demikian, menurut pertimbangan politik dan psikologi sosial, sikap fundamentalis ini tidak sepenuhnya menguntungkan,

43 Chandra Muzaffar, "Kebangkitan Kembali Islam: Tinjauan Global, dengan Ilustrasi dari Asia Tenggara," dalam Taufik Abdullah dan Sharon Siddique, Tradisi dan Kebangkitan Islam di Asia Tenggara (Jakarta: LP3ES, 1988), h. 7-57.

44 Fazlur Rahman, "Roots of Islamic Neo-Fundamentalism," dalam Philip H. Stoddard, David C. Cuthell dan Margaret W. Sullivan (eds.), Change and the Islamic World (Syracuse, NY: Syracuse University Press, 1981), h. 23-39. 
terlebih bahwa reaksi ini serupa dengan kemarahan struktural kolektif, yang justru membenamkan sikap dewasa tatkala semestinya masyarakat Islam lebih memerlukan negosiasi kebudayaan.

Di sisi lain, masyarakat Islam juga dituntun dan dikendalikan secara penuh oleh trend yang diciptakan untuk kepentingan kapitalisme. Kebudayaan populer, lebih dahsyat dan melenakan dari pada sekedar fundamentalisme yang reaktif. Arus trend populer ini, menjadikan banyak agenda penting dari masyarakat Islam terbengkalai. Semestinya masyarakat Islam menaruh perhatian untuk memperbaiki diri dari pada krisis sosial kemanusiaan. Namun kenyataannya, sebagian besar umat lebih cenderung pada kehidupan yang hedonis, materialistis dan patuh pada urusan akumulasi kapital. Kendati secara teologis al-Quran memiliki penilaian terhadap kecenderungan hedonisme, misalnya dalam surat alTakatsur (bermakna konglomerasi atau hedonism), ${ }^{45}$ nyatanya umat telah gagal menggali kesadaran kemanusiaan, terlebih terlibat dalam praksis transformasi sosial.

Sesuatu hal dikatakan benar, jika ia sesuai dengan trend dan gaya pasar. Korean Pop, Westernisme, McDonalisme, Amerikanisme dan Inggrisisme adalah semacam kiblat yang harus menjadi rujukan dalam kehidupan sehari-hari. Alpa pada trend ini, maka seseorang akan menjadi individu yang "asing" di hadapan masyarakat yang semestinya. Padahal, masyarakat yang lazim, wajar dan semestinya, adalah masyarakat yang terenggut kesadaran dirinya di hadapan teologi pasar.

\section{Penutup dan Rekomendasi Teoretis: Membangkitkan Kembali Ruh Profetisme Muhammadiyah}

Sangat jelas bahwa pelbagai masalah yang dihadapi seluruh masyarakat, khususnya Muhammadiyah, dewasa ini, memerlukan solusi. Globalisasi dengan segala perangkat dan kondisinya merupakan musuh yang sepadan di hadapan Muhammadiyah yang telah berusia satu Abad lebih.

Secara teologis, Muhammadiyah yang hidup dalam naungan prinsip dan spirit profetisme, jelas mampu menyelesaikan masalah ini dengan baik. Nilainilai etis yang universal dari agama, menjadi semacam struktur yang menuntun kepada kemaslahatan umat, hingga hari akhir nanti (li al-shalah al-ibad dunyahum wa ukhrahum).

45 Al-Quran Surat al-Takatsur ayat 1 berbunyi, “Bermegah-megahan telah melalaikanmu.” Bermegahmegahan di sini, secara historis adalah perilaku masyarakat Borjuis Mekkah tatkala itu. Secara filosofis, dapat dimengerti bahwa perilaku duniawi yang berlebihan disebut dengan hedonis. 
Disfungsi sosial kemanusiaan pada agama, kematian agama dan pelbagai ketidakberdayaan agama untuk menyelesaikan persoalan kekinian, terjadi karena adanya anggapan bahwa agama adalah ide belaka. Inilah akar masalah yang sangat fundamental, yang kadangkala gagal ditangkap oleh sebagaian orang. Menanggapi hal ini, Kuntowijoyo menyebut bahwa agama yang demikian adalah agama mistis. Agama yang tidak menyentuh realitas. Karena itu, ia menggagas ide tentang demistifikasi:

“...kiranya yang sesuai dengan keperluan kita ialah mistik kenyataan. Agama kehilangan kontak dengan kenyataan, dengan realitas, dengan aktualitas, dengan kehidupan. Dengan kata lain, teks kehilangan kontes. Demistifikasi dimaksudkan sebagai gerakan intelektual untuk menghubungkan kembali teks dan konteks. Supaya antara teks dan konteks ada korespondensi, maka ada kesinambungan.” 46

Mempelajari agama, berarti mencoba memahami eksistensi agama sejak kelahirannya. Dengan demikian, agama adalah agama masa lalu, atau agama adalah sejarah. Padahal menurut sudut pandang filsafat, setiap sejarah adalah ide. Di titik inilah agama menjadi ide yang renik, tatkala tidak memberi sumbangsih pada problem kekinian dan upaya pembangunan masa depan.

Ironisnya, hal semacam ini dibiarkan terjadi dan berulang terus-menerus. Ide agama tidak pernah dianggap sebagai ibrah, atau petunjuk yang bermuatan nilai etis universal, sehingga bisa diterapkan dalam kehidupan riil. Padahal kitab suci menerangkan bahwa, "Wahai orang yang beriman, bertakwalah kepada Tuhan dan hendaklah kalian menaruh perhatian yang lebih pada persoalan masa depan" (wa al-tandzur nafsumma qaddamat ligat), atau dalam pernyataan lain, "Dan betapa masa depan itu lebih baik, dari masa sebelumnya" (wala al-akhiratu khairullaka min al-ula).

Malahan bahwa, partikularitas agama tertentu, justru dijunjung tinggi sebagai kebudayaan dan peradaban yang unggul. Di dalam Islam misalnya, seseorang dianggap saleh, jika ia bercita-rasa Arabsentris. Dengan jenggot, pakaian jubah, sorban, jilbab yang panjang lebar dan berbahasa serta segala hal yang serba Arab, akan dianggap lebih dekat dengan Tuhan, dari pada mereka yang berbudaya lain. Meskipun sebenarnya, kebudayaan selalu bersifat relatif dan senantiasa mengalami pembaruan. Tetapi absolutisme kebudayaan, seolah menjadi trend di sebagian umat Islam.

46 Kuntowijoyo, Islam sebagai Ilmu (Jakarta: Teraju, 2004), hal. 10. 
Segala problem ini terjadi, karena tidak ada sifat kritis dalam pemikiran keagamaan. Alpa pemikiran kritis, pengertian terhadap sejarah menjadi superfisial. Hal ini pasti bermuara pada dua hal: yaitu romantisme dan penyimpangan ideologi. Sekali lagi, agama bukan lagi untuk memerdekakan umat dari segala tindak laku yang dehumanistik, karena maknanya telah berpaling entah ke mana. Romantisme sejarah (agama) membuat umat hanya berangan tentang masa lalu tanpa ujung pangkal yang jelas akan realitas, sedangkan penyimpangan ideologi membuat agama menjadi lesu di hadapan problem kekinian.

Kita perlu membangun nalar kritis agama. Nalar kritis agama adalah asas penting untuk reformulasi pemikiran kaum bergama. Nalar kritis maksudnya, para pengkaji agama tidak terlena sehingga gagal untuk membuat agama berfungsi sosial di tengah masyarakat. Karena itu, perspektif kritis sangatlah perlu, karena hal ini membolehkan kita untuk campur tangan dalam proses keberlangsungan sejarah. Segala hal yang membawa pada kemunduran, - termasuk ketumpulan kritisisme sejarah - seyogyanya tidak boleh dibenarkan untuk bertahan.

Menimbang hal pelik ini, manusia perlu menggunakan sejarah masa silam untuk mempengaruhi hari ini. Selaras dengan hal tersebut, mengafirmasi pentingnya sejarah, jangan sampai hal itu menutup mata kita dari realitas untuk menghadapi hari depan. Itulah sebabnya, nalar kritis akan membangunkan manusia dari tidur dogmatis keagamaan. Nalar kritis juga akan menyalakan lampu-lampu yang menerangi "ide" agama, sehingga bermuara kepada aksi sosial. Kritisisme sejarah dapat membebaskan kita dari belenggu pemikiran, yaitu membongkar segala mitos masa lalu yang membawa pada kemudharatan masa kini.

Umat beragama tidak perlu terlalu lama membicarakan soal-soal kredo keagamaan yang tidak pernah selesai, sementara kelaparan terjadi di mana-mana. Syahadat, tauhid, akidah dan ajaran agama lainnya, bukanlah sarana untuk permainan intelektual saja. Agama harus melampaui dunia historis-idealis, sehingga terwujud dalam pelbagai praktik pemerdekaan sosial seperti penerapan demokrasi, pemerintahan yang baik dan bersih dari segala aktivitas korupsi.

Memperjelas ide "fungsionalisasi" agama, paling tidak ada, ada tiga hal sebagai rekomendasi revitalisasi pemikiran keagamaan. Pertama, para kaum beragama harus berpijak pada falsafah sejarah masa kini dan masa depan, tidak hanya masa lampau. Kedua, kaum beragama harus percaya diri dan opitimis dalam menghadapi segala realitas kekinian. Ketiga, setiap kaum beragama harus memiliki kesadaran bahwa ide dan realitas keagamaan harus selaras, koheren dan saling menunjang satu sama lain. 
Sebagai penutup dari tulisan ini, semoga dengan berevitalisasi, agama yang sejak semula dianggap adiluhung, melangit dan tidak terjangkau para papa, menjadi lebih membumi dan manusiawi. Inilah yang dimaksud dengan profetisme, suatu ide dan nilai etis yang melampaui zaman. Muhammadiyah sebagai lembaga keagamaan, dituntut agar mampu mempertahankan kekuatan profetisme ini, di hadapan segala tantangan zaman, termasuk globalisasi. []

\section{Bibliografi}

Abdurrahman, Asjmuni, Manhaj Tarjih Muhammadiyah, Metodologi dan Aplikasi. Yogyakarta: Aditya Media dan PSIK Universitas Muhammadiyah Malang, 2000.

Abdurrahman, Moeslim, Islam Transformatif. Jakarta: Pustaka Firdaus, 1997. Abdurrhaman, Moeslim, Islam Sebagai Kritik Sosial. Jakarta: Erlangga, 2003. Alwee, Azhar Ibrahim, "The Making of Progressive Religion," Islam, Religion and Progress, Critical Perspective. Singapore: the Reading Group, 2006.

Arifin, Syamsul, Al-Islam dan Kemuhammadiyahan (AIK) sebagai Basis Pendidikan Nilai. Paper dipresentasikan pada Seminar Pekerti Universitas Muhammadiyah Malang. 8-9 Februari. Malang: UMM: 2012, hal. 2.

Bachtiar, Hasnan, "Menggugat Ekonomisme Pendidikan," Social Critiques and Commentaries. Singapore: Leftwrite Center and the Reading Group of Singapore, 2011.

Beck, Herman L., "The Borderline between Moslem Fundamentalism and Moslem Modernism: An Indonesian Example," dalam Jan Willen Van Henten dan Anton Houtepen (eds.). Religious Identity and the Invention of Tradition. The Nethelands: Koninklijke Van Gorcum, 2001.

Charles Hirschman, "America's Melting Pot Reconsidered," JSTOR: Annual Review of Sociology, Vol. 9, (1983), hal 397-423.

Effendi, Djohan, Pembaruan Tanpa Membongkar Tradisi. Wacana Keagamaan di Kalangan Generasi Muda NU, Masa Kepemimpinan Gus Dur. Jakarta: Kompas, 2010.

Engineer, Asghar Ali, Islam and Liberation Theology: Essays on Liberation Elements in Islam. New Delhi: Sterling Publishers, 1990.

Fakih, Mansour, The Role of Non-governmental Organizations in Social Transformation: A Participatory Inquiry in Indonesia. Dissertation in the University of Massachusetts at Amherst, 1995. 
Fanon, Frantz, The Wretched of the Earth. New York: Grove Press, 2004.

Freire, Paulo, Pedagogy of the Oppressed. New York: the Continuum International Publishing Group Inc., 2000.

Fromm, Erich, The Fear of Freedom. London: Routledge Classics, 2001.

Freire, Paulo, Pedagogy of Hope: Reliving Pedagogy of the Oppressed. New York: the Continuum International Publishing Group Inc., 2006.

Freire, Paulo, Education for Critical Consciousness. New York: the Continuum International Publishing Group Inc., 2007.

Garaudy, Roger, Janji-Janji Islam. Jakarta: Bulan Bintang, 1985.

Geertz, Clifford, The Interpretation of Cultures. New York: Basic Book, 1977.

Greta R. Krippner, "The financialization of the American economy," Oxford Journals of Economics $\mathcal{E}$ Social Sciences, Socio-Economic Review, Vol. 3, Issue 2, (2005), hal 173-208.

Gutierrez, Gustavo, A Theology of Liberation: History, Politics, and Salvation. New York: Orbis Books, 1988.

Ishomuddin, "Interdisiplin Menuju Pemahaman Menyeluruh; Kegelisahan Seorang Sosiolog Wallerstein,” Tarjih dalam Pendekatan Ilmu-Ilmu Sosial: Mengupayakan Praktek Interdisipliner dalam Bertarjih. Paper dipresentasikan dalam Workshop Metodologi Tarjih Pusat Studi Islam dan Filsafat UMM. 5 Mei 2012. UMM. hal 2-8.

Kristi, Ellen, Cinta yang Berpikir: Sebuah Manual Pendidikan Karakter Charlotte Mason. Semarang: Ein Institute, 2012.

Kuntowijoyo, "Islam dan Kelas Sosial: Upaya Konseptualisasi," Paradigma Islam: Interpretasi untuk Aksi. Bandung: Mizan, 1991.

Kuntowijoyo, "Jalan Baru Muhammadiyah," dalam Abdul Munir Mulkhan. Islam Murni dalam Masyarakat Petani. Yogyakarta: Yayasan Bentang Budaya, 2000.

Kuntowjoyo, Muslim Tanpa Masjid. Bandung: Mizan, 2001.

Kuntowijoyo, Maklumat Sastra Profetik. Yogyakarta: Grafindo Litera Media, 2006. Kuntowijoyo, Islam sebagai Ilmu: Epistemologi, Metodologi dan Etika. Yogyakarta: Tiara Wacana, 2006.

Kurniawan Lutfi J., "Sekolah Filsafat II: Poskolonialisme dan Syed Hussein Alatas." Kuliah umum di Pusat Studi Islam dan Filsafat (PSIF) Universitas Muhammadiyah Malang pada 15 Juli 2011. Malang. 
Mulkhan, Abdul Munir, Manusia al-Quran: Jalan Ketiga Religiositas di Indonesia. Yogyakarta: Kanisius, 2007.

Nye Jr., Joseph S., "The American Colossus," The Paradox of American Power: Why the World's Only Superpower Can't Go It Alone. New York: Oxford University Press, 2003.

Pradana Boy ZTF., "Prophetic Social Sciences: Toward an Islamic-Based Transformative Social Sciences," IJIMS: Indonesian Journal of Islam and Muslim Societies, Vol. 1, No. 1, (Juni 2011), hal. 95-121.

Prasetyo, Eko, Astagfirullah: Islam Jangan Dijual. Yogyakarta: Resist Book, 2007. Priyono, A.E., "Periferalisasi, Oposisi dan Integrasi Islam di Indonesia. Menyimak Pemikiran Dr. Kuntowijoyo,” Kuntowijoyo. Paradigma Islam: Interpretasi untuk Aksi. Bandung: Mizan, 1991.

Putra, Heddy Sri-Ahimsa, "Paradigma Profetik: Mungkinkah? Perlukah?” Paper dipresentasikan pada Sarasehan Profetik 2011 Sekolah Pascasarjana UGM. 10 Februari. Yogyakarta, 2011. hal. 6.

al-Qurtuby, Sumanto, Lubang Hitam Agama: Mengkritik Fundamentalisme Agama, Menggugat Islam Tunggal. Jakarta: Rumah Kata, 2005.

Rahardjo, Dawam, "Ilmu Sejarah Profetik dan Analisis Transformasi Masyarakat," Kuntowijoyo. Paradigma Islam: Interpretasi untuk Aksi. Bandung: Mizan, 1991.

Rais, Amien, Agenda Mendesak Bangsa, Selamatkan Indonesia. Yogyakarta: PPSK Press, 2008.

Ridwan, Nur Khalik, Islam Borjuis dan Islam Proletar: Konstruksi Baru Masyarakat Islam Indonesia. Yogyakarta: Galan Press, 2002.

Sarbiran, "Pendidikan Islam dan Tantangan Globalisasi Ditinjau dari Aspek Ekonomi dan Politik." Imam Machali dan Musthofa (eds.). Pendidikan Islam dan Tantangan Globalisasi. Buah Pikiran seputar Filsafat, Politik, Ekonomi, Sosial dan Budaya. Yogyakarta: Ar-Ruzz Media, 2004.

Samuel Bowles, David M. Gordon dan Thomas E. Weisskopf, "Power and Profits: The Social Structure of Accumulation and the Profitability of the Postwar U.S. Economy," Sage Journals: Review of Radical Political Economics, Vol. 18, No. 1-2 (SPRING \& SUMMER 1986), hal 132-167.

Santoso, Purwo, Ilmu Sosial Transformatif. Paper dipresentasikan pada Pidato Pengukuhan Guru Besar Universitas Gadjah Mada. 19 April 2011. Yogyakarta. 
Shiraishi, Takashi, An Age in Motion. Popular Radicalism in Java, 1912-1926. Ithaca: Cornel University Press, 1990.

Styarso Budy (eds.), Tjokroaminoto. Guru para Pendiri Bangsa. Jakarta: Kepustakaan Popular Gramedia, 2011.

\section{Sumber Lain}

Tabrani, Roni, "Muhammadiyah Harus Melakukan Akselerasi." http:// www.muhammadiyah.or.id/id/news-832-detail-muhammadiyah-harusmelakukan-akselerasi.html (diakses pada 9 Maret 2012).

http://mdc.umm.ac.id/ (diakses pada 9 Maret 2012). 